\title{
Evaluation of the Effectiveness of English Language Instruction based on the ASSURE Model
}

\author{
Dr. Mehmet Altın \\ Aydin Adnan Menderes University - Turkey \\ ORCID: 0000-0002-3825-6728 \\ mehmet.altin@adu.edu.tr
}

\begin{abstract}
A great importance is given to English Language Teaching all over the world because of several reasons. However, it was found that there is a need for studies to evaluate teaching English in the literature. Thus, this study aimed to evaluate the effectiveness of English language instruction based on the ASSURE model. The acronym ASSURE stands for six basic stages; 1. Analyze learners, 2. State objectives, 3. Select media and materials, 4. Utilize media and materials, 5. Require learner participation and 6. Evaluate and revise. The research was structured in an embedded design, one of the mixed research method. While the quantitative phase of the study was designed as a quasi-experimental model, the qualitative phase was designed as a case study. Selected with multi-stage sampling method, two of the seventh grade classes of a school in Aydın Province in the spring semester of the 2018-2019 academic year were assigned as the experimental group and the control group. The "Environment" unit of the experimental group was adapted according to the ASSURE instructional design model. It was examined whether there was a statistically significant difference between the change in English pre-test and post-test success scores of the experimental group and the control group. In addition, a questionnaire consisting of open-ended questions about instructional design was applied to the students o examine the effectiveness of instructional design where the qualitative data were analyzed using content analysis technique. According to the findings, students generally enjoyed the activities and materials; however, they had difficulties especially in activities such as reading texts and verbal questionanswer activities. In conclusion, the lessons prepared according to the ASSURE model were found to be successful in general by the students, and the objectives were achieved. Thus, some recommendations were made for the lesson to be more effective and efficient.
\end{abstract}

Keywords: The ASSURE model, English language teaching, Evaluation of instruction.

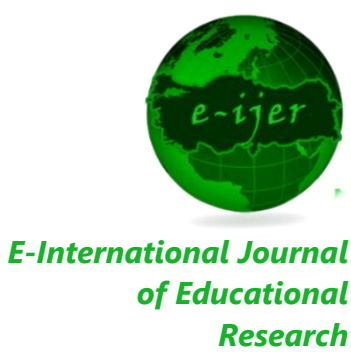

Vol: 12, No: 5, pp. 195-211

Research Article

\section{Suggested Citation}

Altın, M. (2021). Evaluation of the effectiveness of English language instruction based on the ASSURE model, E-International Journal of Educational Research, 12(5), 195-211. DOI: https://doi.org/10.19160/e-ijer.1018149 


\section{INTRODUCTION}

There are many languages spoken by different nations around the world; however, the use of some languages crosses the borders and assumes a universal language identity according to the purpose of use. The most prominent of these languages is English. Knowing English is of vital importance in our age, where human relations and communication have gained an intercontinental dimension (Celce-Murcia, Brinton \& Snow, 2014). Moreover, learning English as a foreign language is the one of the primary actions of people desiring to change their lives (Maxom, 2009). In Turkey, as in many countries, great importance is attached to English education. Thus, great efforts are made to learn English; however, it is thought that the desired level cannot be reached in English education (Demirel, 2012). Therefore, effective lessons should be designed for teaching English (I.S.P. Nation \& Macalister, 2010, Richards, 2017).

Although the concepts of instructional design and curriculum development refer to two separate processes, they are related to each other. This situation creates similarities and differences with each other and, therefore, leads to confusion about the boundaries of the two concepts. "Curriculum" is more concerned with what to teach, while "instruction" is concerned with how to teach. Thus, it can be thought that curriculum development is the processes carried out to determine what will be taught, that is, what the learning goals and objectives will be, and instructional design is the processes carried out to determine how these goals will be gained (Fer, 2011). Instructional design includes mapping out for the planning, development, evaluation and maintenance of instructional processes to increase learners' performance and competence (Seels \& Glasgow, 1998). There are design models developed by different designers in accordance with their opinions (Gagne, Wager, Golas \& Keller, 2005). Each model contributes a lot to educational needs, purposes and settings (ibrahim, 2015). The main well-known instructional design models are ADDIE, the Smith and Ragan model, the Dick, Carey and Carey model, the ARCS model of motivation, The Seels and Glasgow ISD model, The Morrison, Ross and Kemp model and the ASSURE model.

ADDIE: ADDIE, which is a short name formed by the first letters of the words "Analyze, Design, Develop, Implement, Evaluate", is not actually a model; it contains the main components of general instructional design models. It expresses a systematic approach to instructional design (Branch, 2009). There is no universally agreed-upon order of stages in ADDIE; it is at the discretion of the instructional designers that which stage will take place in which order or whether repeated transitions and flashbacks will be made between the stages.

The Smith and Ragan Model: The Smith and Ragan model is a design model based on a pragmatic approach on the basis of the systems approach and explains instructional design and learning accordingly. According to Smith and Ragan (1999), the instructional design process begins with the "analysis" of performance goals. This is followed by the organization of instructional "strategy", and the final stage is the "evaluation" process.

The Dick, Carey and Carey Model: Dick, Carey and Carey (2010)'s step-by-step design model includes a series of events and phenomena in which the designer determines learning goals and instructional strategies to achieve these goals. There are 10 components in that model related to each other directly.

The ARCS Model of Motivation: Keller (1987) says that he aims to create a systematic and useful approach that does not ignore the motivation component in instructional design. In order to achieve this goal, he transformed the instructional design model he had previously developed in the light of the motivation factor. He changed the names of all four components to suit the content he expressed. The four components that show what it takes for a person to be motivated emerged in the last case: attention, relevance, confidence, satisfaction. 
The Seels and Glasgow ISD Model: The 'Seels and Glasgow ISD (instructional system development) model' developed by Seels and Glasgow (1998) consists of five basic stages for instructional systems design processes. This linear model is also known as generic modeling which means general, comprehensive, all-encompassing modelling. The model consists of ten steps that include five interrelated and interactive key stages.

The Morrison, Ross and Kemp Model: The Morrison, Ross and Kemp model consists of four fundamental components; "learner", "objectives", "method" and "evaluation". Morrison, Ross and Kemp (2004) suggested nine elements of an instructional design process.

The ASSURE Model: The ASSURE model, unlike other design models, is more micro-scaled and is an instructional design model developed for teachers to use in the classroom (Şimşek, 2014). For this reason, the ASSURE Model is described as a classroom-oriented instructional design model. In addition, Smaldino, Lowther and Mims (2019) suggested the ASSURE model as a lesson plan pattern which can be applied from the local to national level. The acronym ASSURE stands for six basic stages (Heinich, Molenda \& Russell, 1993);

1. Analyse learners: It is the stage of examining the general characteristics, entry characteristics and learning styles of the target population.

2. State objectives: It is the stage of determining the objectives. Objectives show the behaviors expected to be observed in the student at the end of the lesson.

3. Select media and materials: It is the stage of determining the most appropriate method and course materials to achieve the objectives.

4. Utilize media and materials: It is necessary to collect the materials needed by the educator and the students, and to determine the order in which the environment and materials will be used.

5. Require learner participation: Learners must actively participate in the lesson for effective learning.

6. Evaluate and revise: It is the stage of evaluating student success, materials and activities and reorganizing the design when necessary.

Studies in the literature asserted the effectiveness of the ASSURE model, one of the classroom-oriented models, in different disciplines. Kim and Downey (2016) examined 39 curricula developed based on ASSURE model and the effects of curricula on promoting student learning. On the other hand, Rahman (2017) investigated effectiveness of the ASSURE model on overcoming difficulties in teaching English, and Karakış, Karamete and Okçu (2016) examined the effects that computer-assisted instruction designed according to the ASSURE. In addition, Sundayana, Herman, Dahlan and Prahmana (2017) examined effectiveness of the ASSURE on mathematical communication ability of learners while Kristianti, Prabawanto and Suhendra (2017) investigated effect of mathematics developed with the ASSURE on critical thinking skills. Therebeside, Reyes and Ores (2017) examined the acceptability level of the developed material using the ASSURE model, and Baran (2010) searched learners' experiences of designing lessons by the ASSURE. However, no study has been found in the literature on the evaluation of the effectiveness of English language instruction designed with the ASSURE model. Therefore, this study contributed to the literature.

To determine the effectiveness of a design, the design needs to be evaluated. According to Uşun (2012), evaluation can be defined as the decision-making process about any feature of a curriculum developed by using scientific research processes based on systematic data collection and analysis such as its accuracy, actuality, adequacy, suitability, efficiency, effectiveness, usefulness, success and being executable. Evaluation in education emerges as a criterion used to reveal whether the desired behavioural changes achieve the expected results according to the criteria determined in the curriculum design (Yüksel \& Sağlam, 2014). Erdem (2011) stated that the evaluation of the educational literature in certain periods both gives information about the quality of the researches made about that period and sheds light on further studies. Accordingly, 
evaluation studies conducted on teaching English in Turkey were examined at YÖK National Thesis Center. It was concluded that a total of 19 thesis studies were conducted in the relevant field by 2019. It was understood that there was a need for studies to evaluate teaching English in the literature. Therefore, the study aims to evaluate the effectiveness of English language instruction based on the ASSURE instructional design model. Depending on the purpose of the research, the sub-problems of the research to be answered are given below:

1. Is there a statistically significant difference between the change in English pre-test and post-test success scores of the experimental group and the control group?

2. What are the students' views about English language instruction carried out according to the ASSURE model?

\section{METHOD}

In the study, the embedded design, one of the mixed research method was applied. The embedded design occurs when the researcher collects and analyzes data in both traditional quantitative and qualitative patterns. In the embedded design, the researcher can add a qualitative phase to a quantitative phase. In the embedded design, the supporting stage is added to somehow enhance the overall design (Creswell \& Clark, 2015). The quantitative phase of the mixed research was designed according to a quasi-experimental model with pretest-posttest control group. While English language instruction based on ASSURE model was applied to the experimental group, English language instruction was conducted in the common manner in the control group. In experimental models, the data to be observed directly under the control of the researcher are produced in order to determine cause-effect relationships (Karasar, 2012). The qualitative phase of the mixed research was designed to the case study method. In case studies, it is aimed to reveal the situations in real life (Creswell, 2013). The main objective in case study is to study intensely on a case (Glesne, 2013). As the case of the present research was a case in a single classroom (Yin, 2009) where the experimental group experienced the English language instruction according to the ASSURE model, the qualitative phase of the research was designed according to the holistic single-case study method.

\section{Study Group}

Selected with multi-stage sampling method, two of the seventh grade classes of a school in Aydın Province in the spring semester of the 2018-2019 academic year were assigned as the experimental group and the control group. Multistage sampling contains multiple steps (Balcl, 2015). Firstly, schools with at least two 7th grade classes at a medium level in terms of English achievement were determined, and one was randomly selected. One of the two classes was assigned as the control group and the other as the experimental group using the cluster sampling method. Information about the number and gender of the participants is shown in Table 1.

Table 1. The number of students and gender

\begin{tabular}{lccc}
\hline \multirow{2}{*}{ Groups } & Number of Students & \multicolumn{2}{c}{ Gender } \\
\cline { 3 - 4 } & 39 & Female & Male \\
\hline Experiment & 38 & 15 & 19 \\
Control & 77 & 35 & 23 \\
Total Number of Participants & 77 & 42 \\
\hline
\end{tabular}




\section{Data Collection and Analysis}

In mixed method, both qualitative and quantitative data are collected and analyzed in a single study (Christensen, Johnson \& Turner, 2015; Creswell \& Clark, 2015). Quantitative data were collected through the achievement test, and qualitative data were collected through open-ended questionnaire developed by the researcher. The achievement test and open-ended questionnaire were developed by the researcher, and opinions of two experts from the department of curriculum and instruction were taken for the validity of the tools. Then, the achievement test was applied to two different classes as the pilot test, and reliability of the test was found to be $K R-20=.9$. Also, the places where students had difficulties in completing the achievement test were determined and resolved for the main implementation. Then, data gathered from the achievement tests at the main implementation was analyzed with two-factor analysis of variance. Also, open-ended questionnaire was applied to two students as a pilot questionnaire and finalized for the main implementation. The data collected through the questionnaires were analyzed and interpreted applying the content analysis method. Content analysis is realized to reveal the relationships and concepts to explain the obtained data (Yıldııım \& Şimşek, 2004). The categories were determined with coding, and as a result, the main themes were obtained. Also, frequency distributions ( $f$ ) and percentage values (\%) were given to quantify the analyzed data (Balcl, 2015).

Development and Implementation of English language Instruction based on ASSURE Model: English language instruction was designed parallel to the English curriculum implemented compulsorily in Turkey. The design was broached to two experts for taking their view on the design; one of the experts is from the department of foreign language education and the other expert is from the department of curriculum development and instruction. Revised after the feedbacks from experts, four-hour part of the design was implemented to a different class as a pilot implementation. In the pilot implementation, problems and challenges were detected and resolved before the main implementation. The implementation of the instructional design lasted for four weeks. The teacher conducted English lessons in both of the experimental and the control group. The instructional design steps of the ASSURE Model applied in the experimental group were interpreted by the researcher:

Analyze learners. The school where the study was conducted is one of the schools with a medium success level in English language instruction. The class in which the design would be developed had 39 students, 20 girls and 19 boys, aged 12-13. It was stated by the teacher that there was a decrease in the interest of the students in the lessons compared to the previous years because they were in the adolescence period. Most of the students preferred to be passive rather than actively participating in the lessons. Students were more prone to visual and verbal learning. In addition, in the achievement test administered by the teacher before starting the unit, it was concluded that the general English achievement status of the class was medium.

State objectives. The objectives aimed to be acquired in the "Environment" unit in the English curriculum implemented compulsorily all over Turkey were determined. According to the curriculum, at the end of the unit, the students:

- tell what the subject of the text is,

- find the requested information from the text,

- make inferences from the text,

- guess the meaning of unknown words in the text,

- prepare posters about the environment with their friends,

- express their feelings verbally,

- express their feelings by writing,

- state their thoughts on the subject,

- write descriptive essays,

- write dialogues in pairs,

- act out the dialogue they write in front of their friends. 
Select media and materials. The activity was carried out in the classroom. Smart board, A3 size drawing papers, working papers, colored pencils, masks, photographs, e-mail message image were used as tools in the lesson.

Utilize media and materials. The activities were carried out in the classroom. The materials used for each activity are given below:

- Smart board: for photo display and listening activity,

- A3 papers and colored pencils: for students to prepare posters,

- Masks: in order for students to express themselves more comfortably in the speaking activity,

- E-mail message image: for students to use as a template in the writing activity,

- Working papers: for students to read the reading passages, to benefit from the descriptive essay and dialogue writing activities.

Also, sample activities given below to illustrate the activities carried out with the experimental group.

\section{Sample activities}

Teacher: "After reading the text about endangered animals, you will work in five-people groups. You will wear the masks and speak as if you were the animal whose mask you have worn. Then, you will express your feelings how you feel as you are an endangered animal."

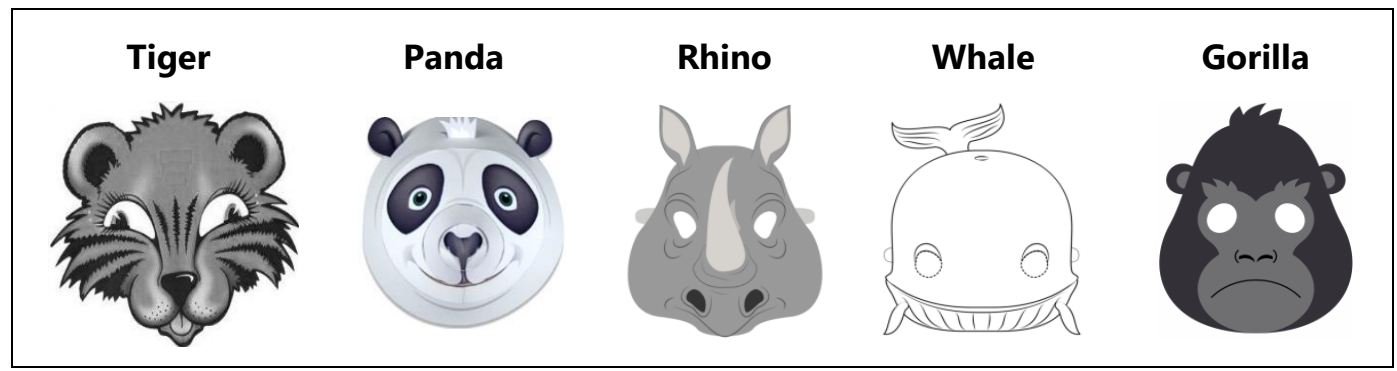

Figure 1. The masks of the endangered animals

Teacher: "Your role still continues; you will write an e-mail to people in the name of the animal whose mask you have worn in order to ask for help from them. You can use the e-mail tmplate."

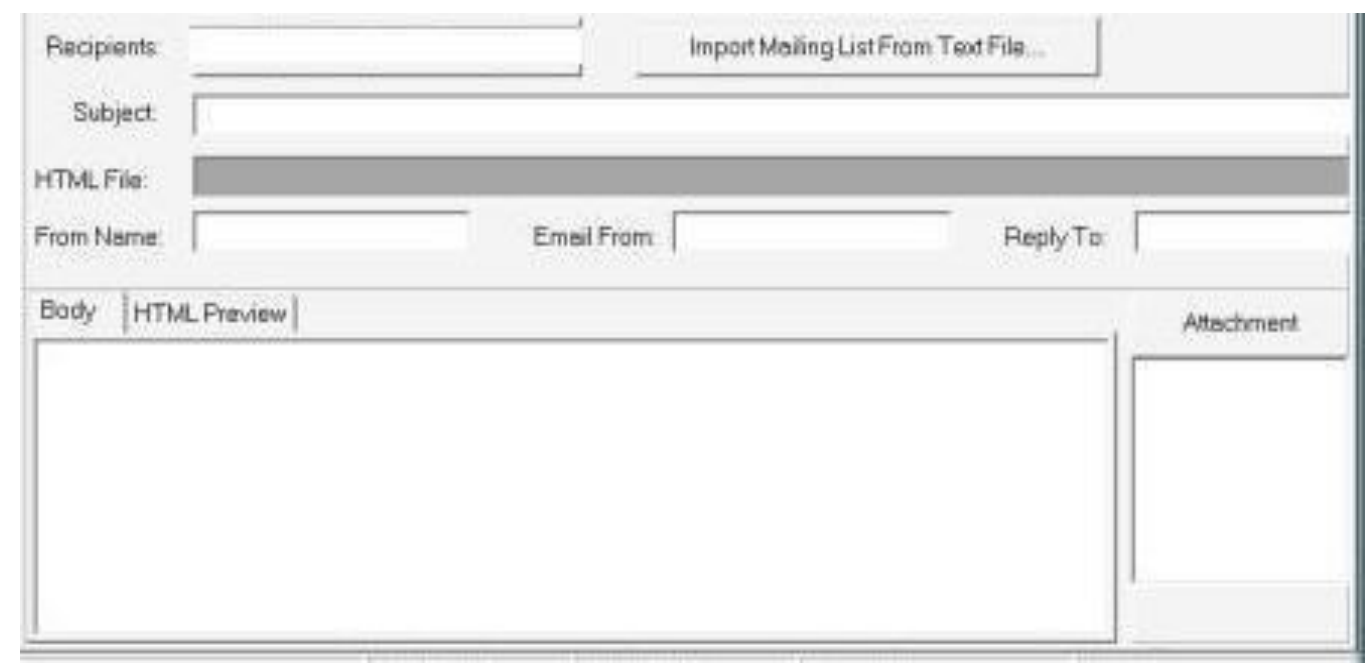

Figure 2. The e-mail template 
Require learner participation. Verbal participation of the students was ensured by asking interest raising questions to the students, especially in the introduction to the activities. In addition, the teacher straggled to make the active participation of the learners by doing pair and group work. Also, the students were in the active participant role in the activities, while the teacher rather assumed the role of a guide.

Evaluate and revise. The teacher asked the students questions in the activities and helped them in their verbal expressions. On the other hand, the teacher followed the activities, guided the students and made the necessary corrections by walking around the working groups in pair or group work while correcting serious spelling mistakes or wording errors in written activities.

\section{FINDINGS}

The results obtained from the research were given in the order of the sub-problems: "Is there a statistically significant difference between the change in English pre-test and post-test success scores of the experimental group and the control group?" and "What are the students' views about English language instruction carried out according to the ASSURE model?"

\section{Findings of the First Sub-Problem of the Research}

In the study, it was tested whether there was a statistically significant difference between the change in English achievement pre-test and post-test scores of the experimental group and the control group. For this reason, two-factor analysis of variance for mixed measurements was used. Whether the normality assumption for the scores of pretest and posttest difference of the experimental and control groups were met was tested with the Kolmogorov-Smirnov test, and it was revealed that the scores of the groups showed normal distribution (KolmogorovSmirnov $=0.2, p>$.05). In addition, Green, Salkind, and Akey (2000) state that when there are 15 or more participants in each cell for variance analysis, the normal distribution assumption can be ignored even if the normality assumption is not met statistically. For this research, the fact that the number of participants was above 15 in the experimental and control groups can be considered as sufficient for the normal distribution assumption. The results of Levene test showed that the variances of the scores of pretest and posttest difference $[F(1.75)=.07, p>.05]$ for the achievement test were homogeneous. According to this result, it was determined that the assumption regarding the equality of variances was provided.

Table 2 shows the arithmetic mean and standard deviation values of the pre-test and posttest scores of each groups regarding English lesson achievement test.

Table 2. English achievement test mean and standard deviation values

\begin{tabular}{lllllll}
\hline \multirow{2}{*}{ Groups } & \multicolumn{4}{c}{ Pre-test } & \multicolumn{3}{c}{ Post-test } \\
\cline { 2 - 7 } & $\boldsymbol{N}$ & $\overline{\mathrm{X}}$ & $\boldsymbol{S}$ & $\boldsymbol{N}$ & $\overline{\mathrm{X}}$ & $\boldsymbol{S}$ \\
\hline Experiment & 39 & 60.15 & 9.210 & 39 & 64.10 & 6.328 \\
Control & 38 & 59.55 & 6.985 & 38 & 60.66 & 4.652 \\
\hline
\end{tabular}

Table 2 shows that the mean score of the participants in the experimental group was $X=60.15$ in the pre-test, and this score increased to $X=64.10$ after the experimental procedure. As the mean score of the control group was $X=59.55$ in the pretest, this value increased to $X=60.66$ after the regular education program. The change in the pre-test and post-test mean scores of the experimental and control groups is stated in the line chart in Figure 1. 


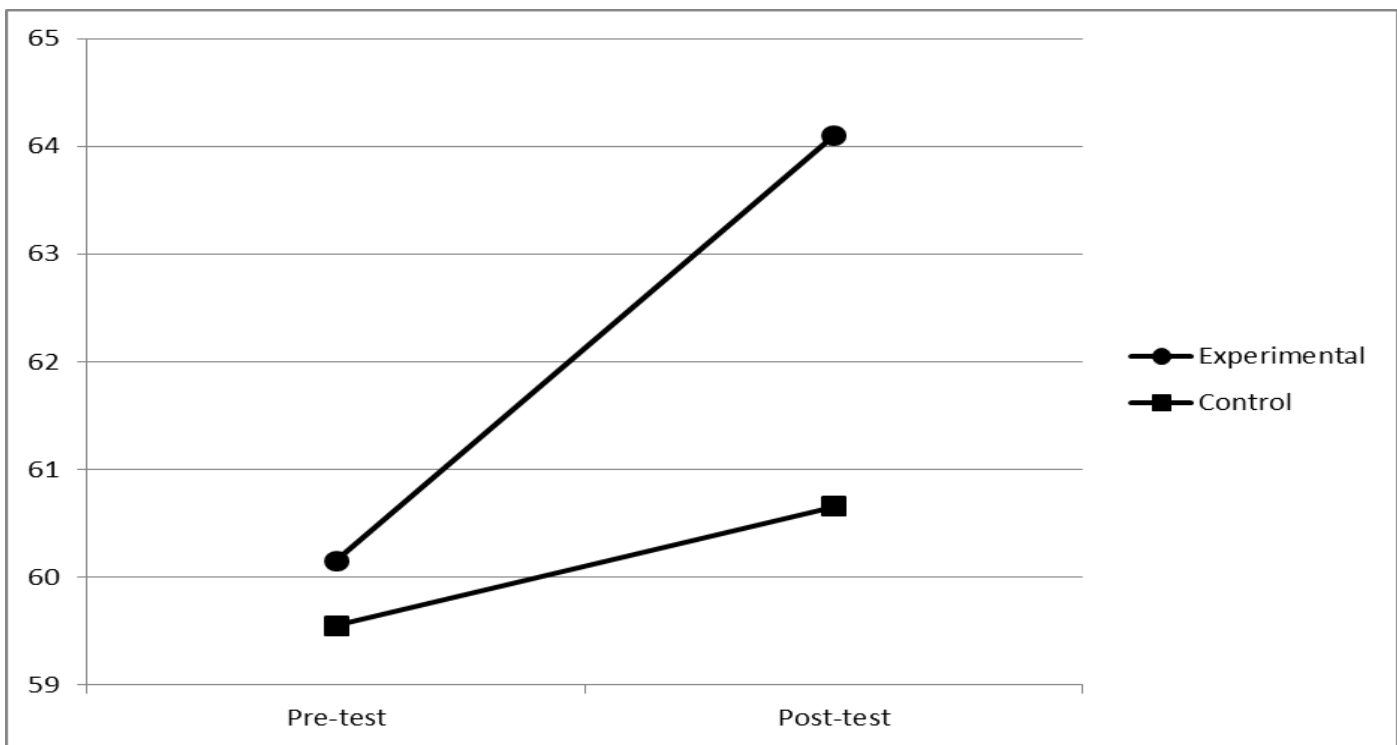

Figure 3. Line chart showing the change in the pretest and posttest mean scores for the achievement test of the experimental and control groups

Figure 3 shows that the achievement test scores of the experimental and control groups were statistically close to each other before the implementation. Figure 3 showed that the change between the pretest and posttest success scores of the experimental group shows a steeper increase compared to the change in the control group. Two-factor analysis of variance results for mixed measurements regarding whether there is a significant difference between the changes in English achievement test scores of students in the experimental and control groups are shown below.

Table 3. ANOVA results of English achievement test pretest-posttest scores

\begin{tabular}{llllll}
\hline Source of the Variance & $\boldsymbol{K T}$ & sd & KO & $\boldsymbol{F}$ & $\boldsymbol{p}$ \\
\hline Inter-subjects & 6663.403 & 76 & & & .182 \\
Groups (Experimental/Control) & 157.527 & 1 & 157.527 & 1.816 & \\
Error & 6505.876 & 75 & 86.745 & & \\
Intra-subjects & 1168.352 & 77 & & & \\
Measurement (Pretest-Posttest) & 245.807 & 1 & 245.807 & 21.824 & .000 \\
Group Measurement & 77.807 & 1 & 77.807 & 6.908 & .010 \\
Error & 844.738 & 75 & 11.263 & & \\
Total & 7831.755 & 151 & & & \\
\hline
\end{tabular}

When Table 3 was examined, it was found that the mean scores of the English achievement test of the students in the experimental and control groups did not differ significantly in terms of before and after the experiment; the common effects of the factors of being in different treatment groups and repeated measures on the English achievement levels of students were not significant $(F(1.75)=6.908, p>.001]$

\section{Findings of the Second Sub-Problem of the Research}

To determine the students' views about the instruction carried out according to the ASSURE model, a questionnaire consisting of open-ended questions about instructional design was applied to the students. The data were examined using content analysis technique and given in Table 4, 5, and 6.

From the analyses, the category "most and least popular activities for students" was reached. The findings related with this category are given in Table 4. 
Table 4. Most and least popular activities for students

\begin{tabular}{lllll}
\hline \multirow{2}{*}{ Activities } & \multicolumn{2}{l}{ Popular activities } & \multicolumn{2}{l}{ Unpopular activities } \\
\cline { 2 - 5 } & $\boldsymbol{f}$ & \% & $\boldsymbol{f}$ & \% \\
\hline Wearing a mask & 33 & 21.29 & & \\
Drama & 25 & 16.13 & 2 & 2.94 \\
Preparing a poster & 23 & 14.84 & 1 & 0.47 \\
Writing an e-mail & 17 & 10.97 & 1 & 0.47 \\
Slides & 13 & 8.39 & 2 & 2.94 \\
All & 12 & 7.74 & & \\
None & & & 11 & 16.18 \\
Writing a descriptive essay & 10 & 6.45 & 5 & 7.35 \\
Reading texts & 8 & 5.16 & 18 & 26.47 \\
Oral question-answer & 7 & 4.51 & 12 & 17.65 \\
Teacher lecturing & 7 & 4.51 & 16 & 23.53 \\
\hline Total & 155 & 100 & 68 & 100 \\
\hline
\end{tabular}

When the opinions of the students about the activities they liked and disliked in teaching were taken, it was found that 33 students (21.29\%) liked wearing masks, 25 students (16.13\%) liked doing dramas, 23 students (14.84\%) liked preparing posters, 17 students (10.97\%) liked writing e-mails, 13 students (8.39\%) liked following the slides, 12 students $(7.74 \%)$ liked doing all the activities, 10 students (6.45\%) liked writing descriptive essays, 7 students (4.51\%) liked oral question-answer activities, and 7 students (4.51\%) liked teacher lecturing. Table 4 shows that 18 students (26.47\%) did not like the reading texts activities, 16 students $(23.53 \%)$ did not like teacher lecturing, 12 students (17.65\%) did not like oral question-answer activities, and 11 students (16.18\%) did not like any of the activities. Sample student views are presented below.

S5: "I loved the colored masks. The lesson was very fun."

S17: "I like drawing; that's why, it was very enjoyable to prepare posters with my friends."

S24: "I don't like the questions the teacher asks us at all. I do not understand anything."

From the analyses, the category "students' views on the materials prepared" was reached. The findings related with this category are presented below.

Table 5. Students' views on the materials prepared

\begin{tabular}{lll}
\hline Views on the materials & $\boldsymbol{f}$ & \% \\
\hline I like it - nice - well prepared & 31 & 17.61 \\
Instructive-informative & 24 & 13.64 \\
Visually rich & 21 & 11.93 \\
Beneficial & 18 & 10.23 \\
Entertaining & 17 & 9.66 \\
Comprehensible & 15 & 8.52 \\
Better than the course book & 14 & 7.95 \\
Interesting & 11 & 6.25 \\
Activities are difficult & 10 & 5.68 \\
Complicated & 8 & 4.55 \\
Could be more fun & 7 & 3.98 \\
\hline Total & 176 & 100 \\
\hline
\end{tabular}

As the opinions of the participants about the prepared materials were taken, it was determined that 31 students (17.61\%) liked the materials; 24 students (13.64\%) found the materials instructive, 21 students (11.93\%) found the materials visually rich, 18 students $(10.23 \%)$ found the materials beneficial, 17 students (9.66\%) found the materials entertaining, 15 students (8.42\%) found the materials comprehensible; 14 students $(7.95 \%)$ thought the materials were better than the coursebook; 11 students $(6.25 \%)$ found the materials interesting; 10 students (5.68\%) found them difficult, 8 students (4.55\%) found the activities complicated, and 7 students (3.98\%) believed that the activities could be better. 
S18: "I think the activities were very good. We did many things we had not done before. We both learned a lot and had fun."

S32: "It was much better than the lessons the teacher taught by reading from the coursebook. I wish all our lessons passed like this. I can say that it was more beneficial than our previous lessons."

S35: "Frankly, I had a hard time in reading texts. It seemed confusing to me; it could have been a little more fun."

From the analyses, the category "general student views about the instruction" was reached. The findings related with this category are shown below.

Table 6. General student views about the instruction

\begin{tabular}{lll}
\hline General views & $\boldsymbol{f}$ & \% \\
\hline Nice-good & 35 & 33.33 \\
Entertaining & 32 & 30.48 \\
I learned better & 14 & 13.33 \\
I liked the lesson more & 12 & 11.43 \\
Boring - sometimes boring & 7 & 6.67 \\
Like the previous lessons & 5 & 4.76 \\
\hline Total & 105 & 100 \\
\hline
\end{tabular}

When the opinions of the participants about the lesson were taken, it was revealed that 35 students (33.33\%) found the lesson nice, 32 students (30.48\%) found the lesson entertaining, 14 students (13.33\%) learned the lesson better, 12 students (11.43\%) liked the lesson with the ASSURE model more than ordinary English lessons, 7 students (6.67\%) found the lesson boring, and 5 students (4.76\%) thought the lessons with the ASSURE model was like the previous lessons.

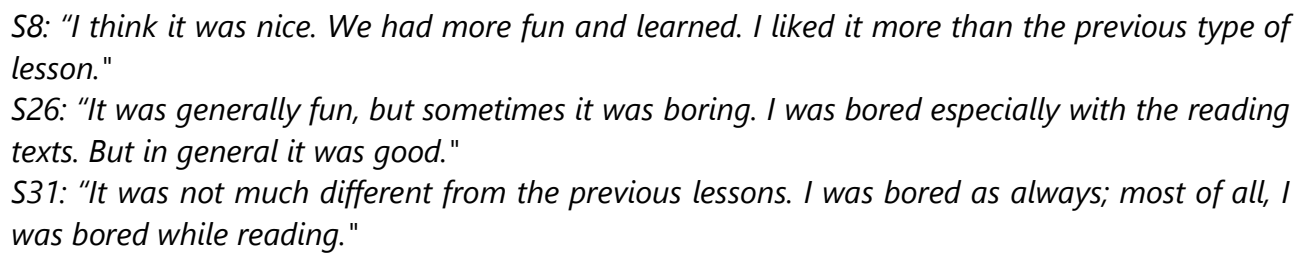

\section{CONCLUSION, DISCUSSION AND RECOMMENDATIONS}

The study aimed to evaluate the effectiveness of English language instruction based on the ASSURE instructional design model. After collecting and analyzing the data, several findings were revealed. The conclusions attained from the findings are as follows:

The effect level of English language instruction based on the ASSURE instructional design model on the English achievement scores of $7^{\text {th }}$ grade students was tested in the study. Although there was a greater increase in success scores in favor of the experimental group, it was concluded from the analysis that this increase was not statistically confirmed. In the research carried out, the design was implemented to the experimental group for four weeks. It can be argued that a longer implementation with groups can yield positive results as Rahman (2017) stated in his study that the ASSURE model is beneficial in overcoming difficulties in teaching English. Also, According to Karakış, Karamete and Okçu (2016), instructions developed with the ASSURE model had positive effects on both students' attitude toward to the lesson and their academic success. Similarly, many studies conducted with the ASSURE instructional design model (Kristianti, Prabawanto \& Suhendra, 2017; Sundayana, Herman, Dahlan \& Prahmana, 2017) concluded that the model was effective in achieving the objectives.

The activities in the lesson designed according to the ASSURE model were enjoyed by most of the students. Kim and Downey (2016) concluded in their studies on effects of curricula on 
promoting student learning that the ASSURE model had a great impact on instruction and learning. The activities that the students generally did not like were the activities in which the teacher was more active and taught through lecturing. Similarly, Çuhadur and Dursun (2010) concluded in their study that the participants wanted to be more active in the activities. Also, Jonassen (2000) emphasized that effective learning can occur as learners participate in the lessons actively. The materials used in the ASSURE instructional design were generally appreciated by the students. Students compared the materials used in the design with the coursebooks they used and said that they were better than the coursebook, but they had difficulty with reading texts. Özbay and Melanlıoğlu (2008) explained that students had difficulty in reading texts, and this was due to the weakness of students' vocabulary while Bahçeci and Yaşar (2007) concluded that participants found the student's books in their English classes boring. On the other hand, Baran (2010) stated that participants had difficulties mostly in designing steps "select methods, media and materials" and "utilize media and materials". Students found the lessons designed with the ASSURE instructional design model to be nice and fun. In a similar way, Özdilek (2006) and Ceylan (2014) stated in their study that the experimental group students had a generally positive opinion about the applied instructional design. However, activities such as reading texts and questionanswer that students found difficult and uninteresting stood out as the disliked and deficient parts of the instructional design developed with ASSURE.

\section{Recommendations}

The lessons prepared according to the ASSURE instructional design model were found to be successful in general by the students, and the objectives were achieved. The following can be suggested for the lesson conducted according to this model to be more effective and efficient:

1. Reading texts had better be organized in a way to attract learners' attention.

2. Comprehensible questions had better be asked to each student according to their level.

3. The design should be enriched with activities in which students will participate more actively in the lessons.

4. Researchers may be recommended to do longer studies on instructional designs.

\section{REFERENCES}

Bahçeci, B. \& Yaşar, M. (2007). Opinions of students attending high schools in Gaziantep about the teaching of English. Gaziantep University Journal of Social Sciences, 6(1), 9-16.

Balcı, A. (2015). Sosyal Bilimlerde Araştırma Yöntem, Teknik ve Ilkeler [Research Methods, Techniques and Principles in Social Sciences] (11 $1^{\text {th }}$ Ed.). Pegem Academy.

Baran, B. (2010). Experiences from the Process of designing lessons with interactive whiteboard: ASSURE as a road map. Contemporary Educational Technology, 1(4), 367-380.

Branch, R. M. (2009). Instructional Design: The ADDIE Approach. Springer.

Celce-Murcia, M., Brinton, D. M. \& Snow, M. A. (2014). Teaching English as a Second or Foreign Language (4 ${ }^{\text {th }}$ Edition). Boston: National Geographic Learning; Heinle Cengage Learning.

Ceylan, S. (2014). A Study for Preparıng an Instructional Design Based on Science, Technology, Engineering and Mathematics (Stem) Approach on the Topic of Acids and Bases at Secondary School Science Course. Unpublished Master's Thesis, Uludağ University Institute of Educational Sciences, Bursa.

Christensen, L. B., Burke Johson, R. \& Turner, L. A. (2015). Araştırma Yöntemleri: Desen ve Analiz [Research Methods: Design and Analysis] (2 ${ }^{\text {nd }}$ Ed.), (Trans. Ed., A., Aypay, ). Anı Publication.

Creswell, J. W. (2013). Beş Yaklașıma Göre Nitel Araștırma ve Araștırma Deseni [Qualitative Inquiry and Research Design: Choosing among Five Approaches] (Translating Eds. M. Bütün and S. B. Demir). Siyasal Bookstore Publishing, 
Creswell, J. W. \& Clark, V. L. P. (2015). Karma Yöntem Araștırmaları Tasarımı ve Yürütülmesi [Mixed Method Research Design and Conduction] (Trans. Ed. Dede, Y. \& Demir, S. B.). Anı Publication.

Çuhadur, C. \& Dursun, Ö.Ö. (2010). The teaching profession through the eyes of information technology teacher candidates. Journal of Educational Technology Research, 1(1), 1-18.

Demirel, Ö. (2012). Yabancı Dil Ögrretimi [Foreign Language Teaching] . Pegem Akademi.

Dick, W., Carey, L. \& Carey, J. (2001). The Systematic Design of Instruction. Long Man.

Erdem, D. (2011). Türkiye'de 2005-2006 yılları arasında yayımlanan eğitim bilimleri dergilerindeki makalelerin bazı özellikler açısından incelenmesi: betimsel bir analiz [Investigation of some properties of the articles published in the Journal of Educational Sciences in Turkey between the years of 2005-2006: A Descriptive Analysis]. Journal of Measurement and Evaluation in Education and Psychology, 2(1), 140-147.

Fer, S. (2011). Öğretim Tasarımı (Instructional Design) (2 ${ }^{\text {nd }}$ ed.). Anı Publication.

Gagne, R. M., Wager, W. W., Golas, K. C. \& Keller, J. M. (2005). Principles of Instructional Design (5 Ed.). Wadsworth: Cengage Learning.

Glesne, C. (2013). Becoming Qualitative Researchers (4th Ed. Translating Eds. Ali Ersoy \& Pelin Yalçınoğlu). Anı Publication.

Green, S. B., Salkind, N. J. \& Akey, T. M. (2000). Using SPSS for Windows: Analyzing and Understanding Data ( $2^{\text {nd }}$ Ed.). Upper Saadle River, NJ: Prentice Hall.

Heinich, R, Molenda, M. \& Russell, J. D. (1993). Instructional Media and the New Technologies of Instruction. New York: Macmillan.

Ibrahim, A. A. (2015). Comparative analysis between System Approach, Kemp, and ASSURE instructional design models. International Journal of Education and Research, 3(12), 261-270.

I.S.P. Nation \& Macalister, J. (2010). Language Curriculum Design. New York: Routledge.

Jonassen, D. H. (2000). Toward a design theory of problem solving. ETR\&D, 48, 63-85. https://doi.org/10.1007/BF02300500

Karasar, N. (2012). Bilimsel Araştırma Yöntemleri [Scientific Research Methods]. Nobel Academic Publication.

Karakıs, H., Karamete, A. \& Okçu, A. (2016). The effects of a computer-assisted teaching material designed according to the ASSURE instructional design and the ARCS Model of motivation, on students' achievement levels in a mathematics lesson and their resulting attitudes. European Journal of Contemporary Education, 15 (1), 105-113.

Keller, J. M. (1987). Development and use of the ARCS model of instructional design. Journal of Instructional Development., 10(3), 2-10. doi:10.1007/bf02905780

Kim, D. \& Downey, S. (2016). Examining the use of the ASSURE model by K-12 teachers. Computers in the Schools, 33(3), 153-168.

Kristianti, Y., Prabawanto, S. \& Suhendra, S. (2017). Critical thinking skills of students through mathematics learning with ASSURE model assisted by software autograph. International Conference on Mathematics and Science Education (ICMSCE).

Maxom, M. (2009). Teaching English as a Foreign Language for Dummies. Hoboken, N. J. : John Wiley $\&$ Sons.

Morrison, G. R., Ross, S. M. \& Kemp, J. E. (2004). Designing effective instruction (4th ed.). John Wiley \& Sons.

Özbay, P. \& Melanlığlu, A. (2008). Importance of vocabulary in Turkish education. Van Yuzuncu Yil University Journal of Education, 5(1), 30-45.

Özdilek, Z. (2006). Instructional Design of a Travel to Inner Structure of Matter Units at Science Course in Primary Education. Unpublished Doctorate Thesis, Uludağ University Institute of Social Sciences, Bursa.

Rahman, H. (2017). Authentic tasks for vocational EFL learners in suburb: ASSURE model using computer-assisted audio-visual. Proceeding: International Seminer on Language, Education and Culture.

Reyes, Y. \& Oreste, J. (2017). Acceptability level of developed material (SAI) using ASSURE model. The Educational Review, 1(3), 61-69. 
Richards, J. C. (2017). Curriculum Development in Language Teaching (2 ${ }^{\text {nd }}$ Edition). Cambrdige.

Seels, B. \& Glasgow, Z. (1998). Making Instructional Design Decisions (2 ${ }^{\text {nd }}$ Edition). Upper Saddle River, NJ: Prentice Hall)

Smaldino, S. E., Lowther, D. L. \& Mims, C. (2018). Instructional Technology and Media for Learning (12 ${ }^{\text {th }}$ Ed.). Boston : Pearson Education, Inc.

Smith, P. L., \& Ragan, T. J. (1999). Instructional Design. John Wiley \& Sons Inc.

Sundayana, R., Herman, T., Dahlan, J., A. \& Prahmana, R. C. I. (2017). Using ASSURE learning design to develop students' mathematical communication ability. World Transactions on Engineering and Technology Education, 15(3), 244-249.

Şimşek, A., Becit, G., Kılıçer, K., Özdamar, N., Akbulut, Y., \& Yıldırım, Y. (2008). Current trends in educational technology research in Turkey. Selcuk University Journal of Social Sciences, 19, 439458.

Uşun, S. (2012). Eğitimde Program Değerlendirme: Süreçler, Yaklaşımlar ve Modeller [Curriculum Evaluation in Education: Processes, Approaches and Models]. Anı Publication.

Yıldııım, A. \& Şimşek, H. (2004). Sosyal Bilimlerde Nitel Araştırma Yöntemleri [Qualitative research methods in the social sciences] (4th Ed.). Seçkin Publication.

Yin, R. K. (2009). Case Study Research: Design and Methods (4 ${ }^{\text {th }}$ Ed.). Beverly Hills, CA: Sage.

Yüksel, İ. \& Sağlam, M. (2014). Eğitimde Program Değerlendirme [Curriculum Evaluation in Education]. Pegem Academy. 


\title{
ASSURE Modeline Dayalt ingilizce Dil Öğretiminin Etkilliğinin Değerlendirilmesi
}

\author{
Dr. Mehmet Altın \\ Aydın Adnan Menderes Üniversitesi - Türkiye \\ ORCID: 0000-0002-3825-6728 \\ mehmet.altin@adu.edu.tr
}

\begin{abstract}
Özet
Ingilizce Öğretimine tüm dünyada çeşitli nedenlerle büyük önem verilmektedir. Ancak alanyazın incelendiğinde ingilizce öğretimini değerlendirecek çalışmalara alanyazında ihtiyaç olduğu görülmüştür. Bu nedenle, bu çalışma ASSURE öğretim tasarımı modeline dayalı olarak Ingilizce ögretiminin etkililiğini değerlendirmeyi amaçlamıştır. ASSURE kısaltması altı temel aşamanın baş harflerinden oluşmaktadır; 1. Öğrenenleri analiz edin, 2. Hedefleri belirleyin, 3. Medya ve materyalleri seçin, 4. Medya ve materyalleri kullanın, 5. Öğrenci katılımını sağlayın ve 6. Değerlendirin ve gözden geçirin. Araştırma, karma araştırma yöntemlerinden biri olan iç içe desende yapılandırılmıştır. Karma araştırma desenindeki bu çalışmanın nicel aşaması ön test-son test kontrol gruplu yarı deneysel bir modele göre tasarlanur iken çalışmanın nitel aşaması durum çalışması yöntemine göre tasarlanmıştır. Çalışma grubu, çok aşamalı örnekleme yöntemi kullanılarak belirlenmiştir. Çalışma grubunu 2018-2019 eğitim-öğretim yılı bahar döneminde Aydın ilinde bulunan bir okulun deney ve kontrol grubu olarak belirlenen iki tane yedinci sınıf oluşturmaktadır. Yedinci sınıf Ingilizce öğretim programında yer alan "Çevre" ünitesi, ASSURE öğretim tasarımı modeline göre düzenlenmiştir. Deney grubu ile kontrol grubunun ingilizce ön test ve son test başarı puanlarındaki değişim arasında istatistiksel olarak anlamlı bir fark olup olmadığına bakılmıştır. Ayrıca öğretim tasarımının etkililiğini incelemek için öğrencilere öğretim tasarımı ile ilgili açık uçlu sorulardan oluşan bir anket uygulanmıştır. Nitel veriler içerik analizi tekniği kullanılarak analiz edilmiştir. Elde edilen bulgulara göre öğrenciler etkinlikleri ve materyalleri genel olarak beğenmişler; ancak özellikle metin okuma ve sözlü soru-cevap etkinlikleri gibi etkinliklerde zorlanmışlardır. Sonuç olarak, ASSURE öğretim tasarımı modeline göre hazırlanan dersler öğrenciler tarafından genel olarak başarılı bulunmuş ve hedeflere ulaşılmıştır. Böylece dersin daha etkili ve verimli geçmesi için bazı önerilerde bulunulmuştur.
\end{abstract}

Araşturma Makalesi

E-Uluslararası Eğitim

Araşturmaları

Dergisi

Cilt: 12, No: 5, ss. 195-211

Anahtar Kelimeler: ASSURE modeli, ingilizce öğretimi, Öğretimin değerlendirilmesi

\section{Önerilen Atıf}

Altın, M. (2021). Evaluation of the effectiveness of English language instruction based on the ASSURE model, E-International Journal of Educational Research, 12(5), 195-211. DOI: https://doi.org/10.19160/e-ijer.1018149 


\section{Genişletilmiş Özet}

Problem: Insan ilişkilerinin ve iletişimin kıtalararası bir boyut kazandığı çağımızda Ingilizce bilmek hayati önem taşımaktadır (Celce-Murcia, Brinton ve Snow, 2014). Ayrıca Ingilizceyi yabancı dil olarak öğrenmek, hayatlarını değiştirmek isteyen birçok insanın da gerçekleştirdiği ilk eylemlerden biridir (Maxom, 2009). Birçok ülkede olduğu gibi Türkiye'de de Ingilizce'nin yabancı dil olarak öğretimine büyük önem verilmektedir. Bu yüzden Ingilizceyi öğrenmek için çok büyük emekler verilmektedir; ancak onca uğraşa rağmen Ingilizce eğitiminde istenilen düzeye ulaşılamadığı düşünülmektedir (Demirel, 2012). Bu nedenle ingilizce öğretimindeki hedeflere ulaşabilmek için etkili dersler tasarlanmalıdır (I.S.P. Nation ve Macalister, 2010; Richards, 2017). Dolayısıyla Ingilzce öğretimi için alan yazında etkinliği kanıtlanmış öğretim tasarım modellerinden faydanılmasına ihtiyaç duyulmaktadır.

Öğretim tasarımı, ögrrencilerin performansını ve yeterliliğini artırmak için öğretim süreçlerinin planlanması, geliştirilmesi, değerlendirilmesi ve sürdürülmesi için planlamayı içerir (Seels ve Glasgow, 1998). Farklı tasarımcıların görüşleri doğrultusunda geliştirdikleri tasarım modelleri bulunmaktadır (Gagne, Wager, Golas ve Keller, 2005). Bu modellerden biri olan ASSURE modeli, eğitim ihtiyaçlarına, amaçlarına ve ortamlarına büyük katkı sağlamaktadır (ibrahim, 2015).

ASSURE modeli, diğer tasarım modellerinden farklı olarak daha mikro ölçeklidir ve öğretmenlerin sınıfta kullanmaları için geliştirilmiş bir öğretim tasarımı modelidir (Şimşek, 2014). Bu nedenle ASSURE Modeli sınıf odaklı bir öğretim tasarımı modeli olarak tanımlanmaktadır. Smaldino, Lowther ve Mims (2019) yerelden ulusal düzeye uygulanabilecek bir öğretim deseni olarak ASSURE modelini önermiştir. ASSURE altı temel aşamadan oluşmaktadır (Heinich, Molenda ve Russell, 1993);

1. Öğrenenleri analiz edin: Hedef kitlenin genel özelliklerini, giriş özelliklerini ve öğrenme stillerini inceleme aşamasıdır.

2. Hedefleri belirleyin: Hedeflerin belirlenmesi aşamasıdır. Hedefler, ders sonunda ögrencide gözlenmesi beklenen davranışları gösterir.

3. Medya ve materyalleri seçin: Hedeflere ulaşmak için en uygun yöntem ve ders materyallerinin belirlenmesi aşamasıdır.

4. Medya ve materyallerden yararlanın: Eğitimci ve öğrencilerin ihtiyaç duyduğu materyallerin toplanması, ortam ve materyallerin hangi sırayla kullanılacağının belirlenmesi gerekir.

5. Öğrenci katıımını sağlayın: Etkili öğrenme için öğrenciler derse aktif olarak katılmalıdır.

6. Değerlendirin ve gözden geçirin: Öğrenci başarısının, materyallerinin ve etkinliklerinin değerlendirilmesi ve gerektiğinde tasarımın yeniden düzenlenmesi aşamasıdır.

Bir tasarımın etkinliğini belirlemek için tasarımın değerlendirilmesi de gerekmektedir. Uşun (2012)'a göre değerlendirme, sistematik veri toplama ve analize dayalı bilimsel araştırma süreçleri kullanılarak geliştirilen bir programın herhangi bir özelliği hakkında doğruluğu, güncelliği, yeterliliği, uygunluğu, etkinliği, kullanışlıı̆ı, başarısı ve yürütülebilirliği gibi karar verme süreci olarak tanımlanabilir. Eğitimde değerlendirme; program tasarımında belirlenen ölçütlere göre istenilen davranış değişikliklerinin beklenen sonuçlara ulaşıp ulaşmadığını ortaya koymak için kullanılan bir ölçüt olarak karşımıza çıkmaktadır (Yüksel ve Sağlam, 2014). Erdem (2011), eğitim alan yazının belirli dönemlerde değerlendirilmesinin hem o döneme ilişkin yapılan araştırmaların niteliği hakkında bilgi verdiğini hem de daha sonraki çalışmalara ışık tuttuğunu belirtmiştir. Bu doğrultuda Türkiye'de Ingilizce öğretimi konusunda yapılan değerlendirme çalışmaları YÖK Ulusal Tez Merkezi'nde incelenmiştir. Incelemeler sonunda 2019 yllına kadar ilgili alanda toplam 19 tez çalışması yapıldığı sonucuna varılmıştır. Alan yazında ingilizce öğretimini değerlendirecek çalışmalara ihtiyaç olduğu anlaşılmıştır. Bu nedenle bu çalışma, ASSURE öğretim tasarımı modeline dayalı olarak Ingilizce öğretiminin etkililiğini değerlendirmeyi amaçlamaktadır. 
Yöntem: Araştırmada karma araştırma yöntemlerinden iç içe desen uygulanmıştır. iç içe desen, araştırmacı hem geleneksel nicel hem de nitel modellerde veri toplayıp analiz ettiğinde ortaya çıar. iç içe desende, araştırmacı nicel bir aşamaya nitel bir aşama ekleyebilir. iç içe desende, araştırma tasarımı güçlendirmek için destekleyici bir aşama eklenmektedir (Creswell ve Clark, 2015). Karma araştırmanın nicel aşaması, ön test-son test kontrol gruplu yarı deneysel bir modele göre tasarlanmıştır. Deneysel modellerde neden-sonuç ilişkilerini belirlemek için doğrudan araştırmacının kontrolünde gözlemlenecek veriler üretilmektedir (Karasar, 2012). Deney grubuna ASSURE modeline dayalı Ingilizce öğretimi uygulanırken, kontrol grubunda ingilizce öğretimi olağan şekilde yapılmıştır. Karma araştırmanın nitel aşaması durum çalışması yöntemine göre tasarlanmıştır. Durum çalışmalarında gerçek hayattaki durumların ortaya çıkarılması amaçlanır (Creswell, 2013). Durum çalışmasında temel amaç, yoğun bir şekilde bir durum üzerinde çalışmaktır (Glesne, 2013). Bu araştırmanın durumu, deney grubunun ASSURE modeline göre Ingilizce öğretimini deneyimlediği tek sınıfta (Yin, 2009) gerçekleşen bir durum olduğundan, araştırmanın nitel aşaması bütüncül tek durum çalışmasına göre tasarlanmıştır.

Çok aşamalı örnekleme yöntemiyle seçilen 2018-2019 eğitim-öğretim yılı bahar döneminde Aydın ilinde bulunan bir ortaokulun yedinci sınıf sinıflarından bir sınıf deney grubu ve bir sinıf kontrol grubu olarak belirlenmiştir. Çok aşamalı örnekleme, birden çok adımı içerir (Balcı, 2015). ilk olarak, Ingilizce başarısı açısından orta düzeyde en az iki 7. sınıf sınıfına sahip okullar belirlenmiş ve bir tanesi rastgele seçilmiştir. Küme örnekleme yöntemi kullanılarak iki sınıftan biri kontrol, diğeri deney grubu olarak atanmıştır.

Karma yöntemde hem nitel hem de nicel veriler tek bir çalışmada toplanır ve analiz edilir (Christensen, Johnson ve Turner, 2015; Creswell ve Clark, 2015). Nicel veriler başarı testi ile nitel veriler ise araştırmacı tarafından geliştirilen açı uçlu anket aracılığıyla toplanmıştır. Başarı testi ve açık uçlu anket araştırmacı tarafından geliştirilmiş, araçların geçerliliği için program ve öğretim bölümünden iki uzmanın görüşü alınmıştır. Daha sonra başarı testi pilot test olarak iki farklı sınıfa uygulanmış ve testin güvenirliği KR-20=.9 olarak bulunmuştur. Ayrıca öğrencilerin başarı testini tamamlamakta zorlandıkları yerler tespit edilerek asıl uygulama için çözümlenmiştir. Daha sonra ana uygulamada başarı testlerinden elde edilen veriler iki faktörlü varyans analizi ile analiz edilmiştir. Ayrıca iki ögrenciye pilot anket olarak açık uçlu anket uygulanmış ve asıl uygulamaya son şekli verilmiştir. Anketler aracılığıyla toplanan veriler içerik analizi yöntemi uygulanarak analiz edilmiş ve yorumlanmıştır. İ̧̧erik analizi, elde edilen verileri açılamaya yönelik ilişkileri ve kavramları ortaya çıkarmak için gerçekleştirilir (Yıldırım ve Şimşek, 2004). Kategoriler kodlama ile belirlenmiş ve bunun sonucunda ana temalar elde edilmiştir. Ayrıca analiz edilen verileri nicelleştirmek için frekans dağlımları (f) ve yüzde değerleri (\%) verilmiştir (Balcı, 2015).

Sonuç ve Öneriler: Araştırmada ASSURE öğretim tasarımı modeline dayalı Ingilizce öğretiminin 7. sını öğrencilerinin Ingilizce başarı puanlarına etki düzeyi test edilmiştir. Başarı puanlarında deney grubu lehine daha fazla artış olmasına rağmen, analizlerden bu artışın istatistiksel olarak doğrulanmadığı sonucuna varılmıștır. Yapılan araştırmada deney grubuna dört hafta boyunca ASSURE modeli uygulanmıştır. Rahman (2017)'ın çalışmasında ASSURE modelinin ingilizce öğretimindeki zorlukların aşılmasında faydalı olduğunu belirttiği için çalışma gruplarıyla daha uzun süreli bir uygulamanın olumlu sonuçlar verebileceği ileri sürülebilir. Ayrıca Karakış, Karamete ve Okçu (2016)'ya göre ASSURE modeli ile geliştirilen yönergelerin hem ögrencilerin derse yönelik tutumları hem de akademik başarıları üzerinde olumlu etkileri olmuştur. Benzer şekilde ASSURE öğretim tasarımı modeli ile yapılan birçok çalışmada (Kristianti, Prabawanto ve Suhendra, 2017; Sundayana, Herman, Dahlan ve Prahmana, 2017) modelin hedeflere ulaşmada etkili olduğu sonucuna varılmıştır.

ASSURE modeline göre tasarlanan dersteki etkinlikler öğrencilerin çoğu tarafından beğenilmiştir. Kim ve Downey (2016), programın öğrencilerin öğrenmesini teşvik etme üzerindeki etkileri üzerine yaptıkları çalışmalarda, ASSURE modelinin öğretim ve öğrenme üzerinde büyük bir 
etkisi olduğu sonucuna varmışlardır. Öğrencilerin genel olarak hoşlanmadıkları etkinlikler öğretmenin daha aktif olduğu ve anlatım yoluyla işlendiği etkinlikler olmuştur. Benzer şekilde Çuhadur ve Dursun (2010) çalışmalarında katılımcıların etkinliklerde daha aktif olmak istedikleri sonucuna varmışlardır. Ayrıca Jonassen (2000), öğrencilerin öğrenme sürecine aktif olarak katıldıkları zaman etkili öğrenmenin gerçekleşebileceğini vurgulamıştır. ASSURE öğretim tasarımında kullanılan materyaller öğrenciler tarafından genel olarak beğenilmiştir. Öğrenciler tasarımda kullanılan materyalleri kullandıkları ders kitapları ile karşılaştırarak ders kitabından daha iyi olduklarını ancak metinleri okumakta zorlandıklarını belirtmişlerdir. Özbay ve Melanlıoğlu (2008) öğrencilerin metinleri okumakta zorlandıklarını ve bunun öğrencilerin kelime dağarcığındaki zayıflıktan kaynaklandığını açıklarken, Bahçeci ve Yaşar (2007) öğrencilerin Ingilizce derslerinde ders kitaplarını sıkıcı buldukları sonucuna varmışlardır. Baran (2010) ise katılımcıların en çok "yöntem, medya ve materyal seçme" ve "medya ve materyalleri kullanma" adımlarını tasarlamada zorlandıklarını belirtmiştir. Öğrenciler, ASSURE öğretim tasarımı modeliyle tasarlanan dersleri güzel ve eğlenceli bulmuşlardır. Benzer şekilde Özdilek (2006) ve Ceylan (2014) çalışmalarında deney grubu öğrencilerinin uygulanan öğretim tasarımı hakkında genel olarak olumlu görüşe sahip olduklarını belirtmişlerdir. Ancak okuma metinleri, soru-cevap gibi öğrencilerin zor ve ilgisiz buldukları etkinlikler, ASSURE ile geliştirilen öğretim tasarımının sevilmeyen ve eksik yönleri olarak öne çıkmıştır.

ASSURE öğretim tasarımı modeline göre hazırlanan dersler ögrenciler tarafından genel olarak başarılı bulunmuş ve hedeflere ulaşılmıştır. Bu modele göre yürütülen dersin daha etkili ve verimli geçmesi için bazı önerilerde bulunulmuştur. Öncelikle, okuma metinleri öğrencilerin ilgisini çekecek şekilde hazırlanmalıdır. Ayrıca her öğrenciye düzeyine göre onların kolaylıķ̧a anlayabileceği sorular sorulmalıdır. Ögretim tasarımı, ögrencilerin derslere daha aktif katılabileceği eğlenceli etkinliklerle zenginleştirilmelidir. Benzer konularda çalışma yapacak araştırmacılara ise daha uzun süreli öğretim tasarımları planlayarak çalışmalar yapmaları önerilebilir. Böylelikle, çalışmalarından elde edilen veriler istatistiksel olarak da anlamlı farklılklar gösterebilir. 